\title{
60 kDa Heat Shock Protein, Mitochondrial
}

National Cancer Institute

\section{Source}

National Cancer Institute. 60 kDa Heat Shock Protein, Mitochondrial. NCI Thesaurus. Code C104340.

$60 \mathrm{kDa}$ heat shock protein, mitochondrial (573 aa, $\sim 61 \mathrm{kDa}$ ) is encoded by the human HSPD1 gene. This protein plays a role in mitochondrial protein folding. 